\section{sciendo}

\title{
The Possibility of Modeling Parts in Production Technology
}

doi:10.2478/mape-2020-0031

Date of submission to the Editor: $03 / 2020$

Date of acceptance by the Editor: 06/2020

MAPE 2020, volume 3, issue 1, pp. 359-373

Tatyana N. Ivanova

ORCID ID: 0000-0003-2284-2949

Tchaikovsky Branch Perm National Research Polytechnic Institute, Tchaikovsky, Russia

\section{Aleksandr I. Korshunov}

ORCID ID: 0000-0002-6797-0541

Federal State Budgetary Institution of Science Udmurt Federal Research Center of the Ural Branch

of the Russian Academy of Sciences Institute of Mechanics, Izhevsk, Russia

\section{Jozef Peterka}

ORCID ID: 0000-0001-6258-6113

Slovak University of Technology in Bratislava, Slovak Republic

\section{Ivan A. Ratnikov}

ORCID ID: 0000-0000-0000-0000

Izhevsk State Technical University named after M.T. Kalashnikova, Izhevsk, Russia

Peter Pokorny

ORCID ID: 0000-0002-5804-8061

Slovak University of Technology in Bratislava, Slovak Republic

\section{INTRODUCTION}

Differential of rear-axle 130-2403010 (Fig. 1) of automobile ZIL-130 (ЗИЛ-130) is a transmission mechanism, which separates torques between pinion shaft andaxle shafts.

The feature of work of differential is in the differential division of power flows, i.e. on the outlet each axle shaft receives from 0 to $100 \%$ of the power from pinion shaft. The ratio between power values on each axle shaft can be any within these limits, with the exception of the correction for the efficiency factor of the differential itself.

The most commonly used machining technologies include turning (Skoric et al., 2008, Ajaja et al., 2020), milling (Pokorny et al., 2012, Vopat et al., 2015) and drilling or boring (Zou et al., 2020, Klaic et al., 2014). The aim is to achieve the desired quality of the machined surface with dimensional accuracy and surface roughness (Beno et al., 2013, Peterka, 2004). The cutting process is characterized by the accompanying phenomena: chip formation, existence of cutting forces, tool wear (Vopat et al., 2013), surface roughness and vibrations (Sentyakov, 2020).

Components are designed in a CAD system. New techniques in CAD systems have been developed to overcome perceived limitations in conventional practice - particularly in dealing with complexity of the parts. 

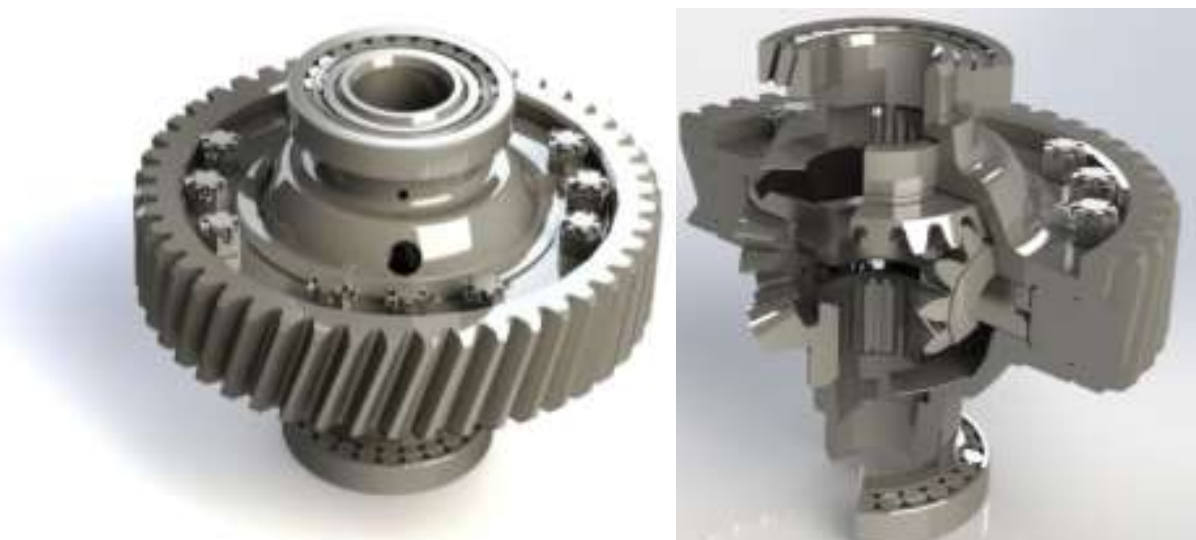

Fig. 13D-modelof a differential of rear axle 130-2403010 in assembly and in section

Computer aided design enables the designer to tackle a task in the practice more quickly and accurately (Xun, 2009). Program for CNC machine tool is generated in CAM system. Machine-tool, tools or machined surface can they be damaged, therefore the program must be simulated and debugged (Jurko et al., 2011).

In addition to machining technology, modern welding (Božek, 2013), robotization (Božek and Pivarčiová, 2012) and automation (Božek, 2014) technologies are used in such cases.

Computer-aided engineering (CAE) software enables to complete engineering analysis tasks with the help of a computer. In essence, CAE software provides a comprehensive optimization of the engineering analysis process through simulations. Modern CAE tools can do more than just run FEM analysis routines; they can also handle multi-body dynamics (MBD), computational fluid dynamics (CFD), stress testing, thermal flow simulations, and much more (Technology Evaluation Centers, 2020).

\section{MATERIALS AND METHODOLOGY}

The "Flange half of differential case"part is case-shaped rotation part of the differential of rear axle of ZIL-130 automobile. The main purpose of the "Flange half of differential case" part is to function as a buffer to prevent the wheels from slipping when turning. It takes the torque from the final drive through a ring gear and transmits it to side gears through spider gears. A differential cross, on which spider gears rotate, is attached to inner side of the case. On the outer surface the ring gear and tapered roller bearing are rigidly fastened (Fig. 2).

The manufacturing of differential case of ZIL-130 automobile started in 1956. It was made of material MSt.6. This steel was made in accordance with requirements of GOST 380-50 "Common quality carbon steel. Grades". Here is the full interpretation of MSt. 6 steel grade: open-hearth steel of group B with a carbon content in the range of $0.38 \ldots 0.50$. A letter $M$ in the name of the steel regulated melting method. If this letter was absent, the steel was referred to group $A$ and the method of manufacturing was chosen by the producing plant. Steel MSt.6 was produced in open-hearth furnaces, which were widespread in times of manufacturing of the part (Luschtinetz, et al., 2019). This manufacturing 
method had a plenty of disadvantages like low economic efficiency, high amount of metal waste, complex and expensive maintenance of the furnaces.

Fig. 2 3D-model of part 130-2403020-2 named "Flange half of differential case"

What is more, it was impossible to produce high-quality steel as melting process was very long, labor productivity was low, while work conditions were harmful and air contamination reached dramatically high level (Leonid et al., 2016, Zhou, 2010).

As for advantages, they included low requirements to the quality of raw materials and an opportunity to re-melt metal scrap. Currently, open-hearth furnaces are not used on the territory of Russian Federation. The last edition of the standard, mentioned above, is GOST 380-2005 "Common quality carbon steel. Grades", which leads to an end oftheMSt. 6 steel grade. In the current standard only steel of former group A remained, while the classification on two groups disappeared. That is why it is necessary to replace the material on the up-to-date analogue, which could meet technical requirements and functional purpose of the part (Thipprakmas and Phanitwong 2011).

The largest overall dimensions of the "Flange half of differential case" are a diameter of $250 \mathrm{~mm}$ and a length of $111.5 \mathrm{~mm}$. Accuracy degree ranges from 14 to 6 , roughness - from $R_{a} 25$ to $R_{a} 0.8$ (Fig. 3 and Fig. 4). The mass of the part is $6.58 \mathrm{~kg}$. In the part there are 12 holes with diameter of $14 \mathrm{~mm}, 4$ holes with diameter of $6 \mathrm{~mm}, 4$ holes with diameter 20 and $28 \mathrm{~mm}$, which are all made by drilling. The group of holes with diameter of $28 \mathrm{~mm}$ is made in assembled differential case. A hole with a diameter of $55 \mathrm{~mm}$ is punched at the stage of creating the workpiece and then machined. Due to the holes with a diameter of $6 \mathrm{~mm}$, grooves with a radius of $\mathrm{R} 2$ and a groove with a diameter of $147 \mathrm{~mm}$, oil is supplied, distributed and retained in the differential working mechanism to ensure lubrication, cooling and corrosion prevention of spider gears and side gears. The most critical surface is the one with diameter of $75 \mathrm{~mm}$ and roughness of $R_{a} 0.8$, onto which the bearing is pressed. Less critical surfaces are located on the outer surface of the differential case in the range of diameters 92-190 $\mathrm{mm}$. These surfaces have radii R20 and R8, they are created in a workpiece by punching without any further machining. External and internal surfaces are machined on CNC lathe equipment. All holes, as well as through grooves with a radius of $\mathrm{R} 2$, are created on CNC milling equipment (Gładysiewicz et al., 2017). 


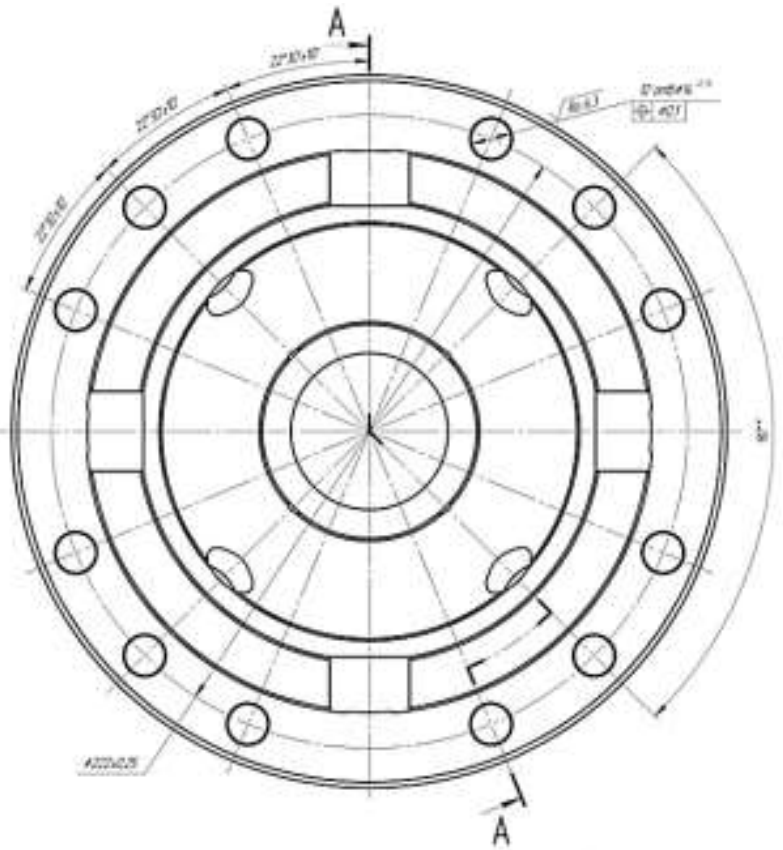

Fig. 3 Drawing of a part 130-2403020-2 "Flange half of differential case". Front view. Kompas 17v software

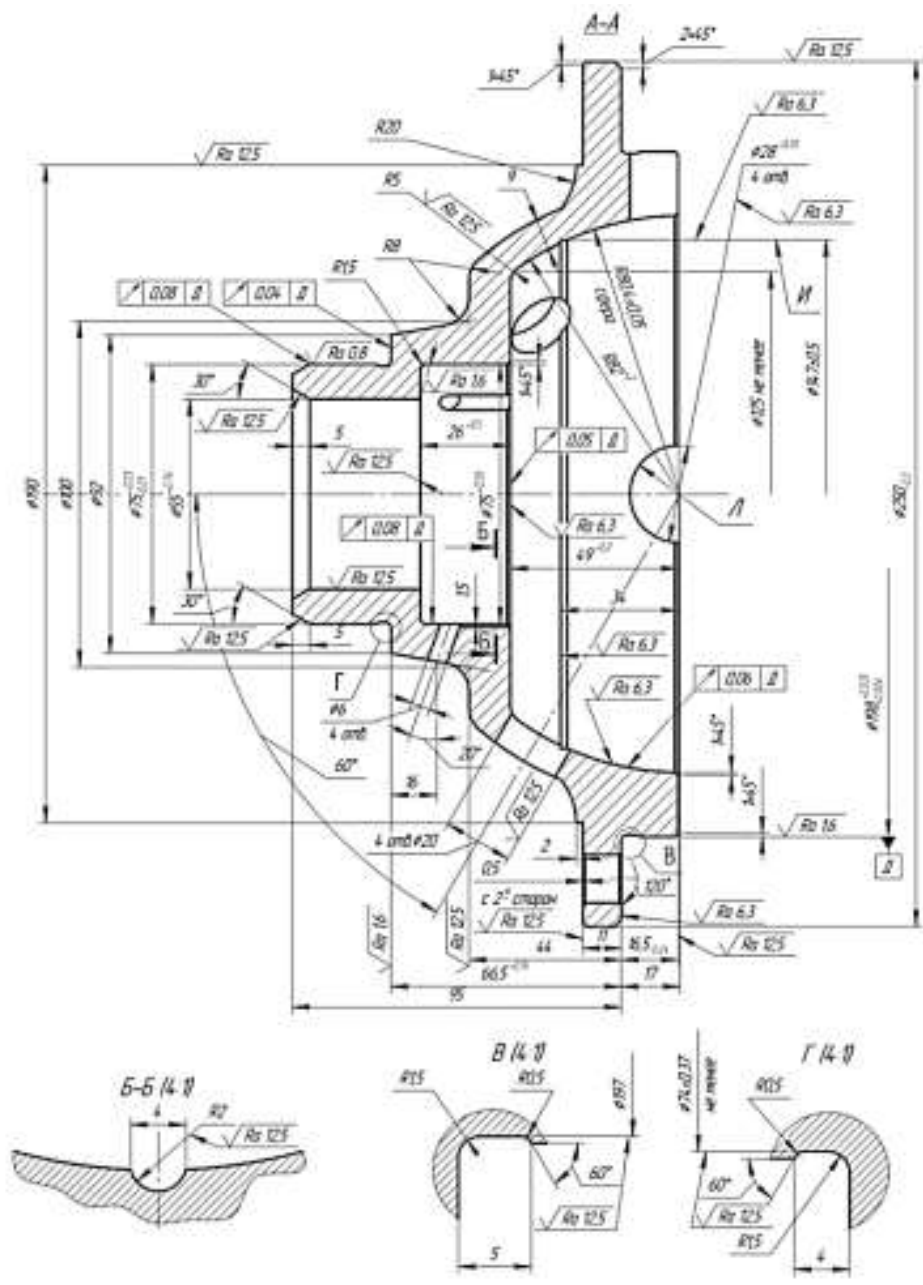

Fig. 4 Drawing of a part 130-2403020-2 "Flange half of differential case". Views A,Б,B,Г. Kompas $17 v$ software 


\section{THE RESULTS}

According to considered data we have carried out an analysis of each of the proposed materials for the part in the Solid Works software. In the Solid Works Library there is no prototype of steelMSt.6, that is why we have created a custom material on the base of the data from GOST 380-50. Wealsoexaminedsteel 45 andsteel 60, whichalready existed in the library and comparedtheir characteristics with the ones declared by GOST 1050-2013 (Fig. 5).

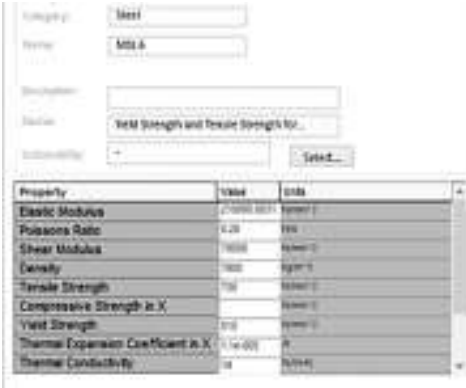

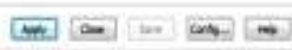

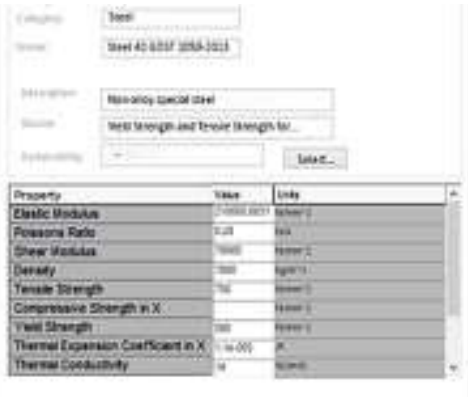

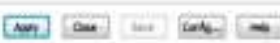

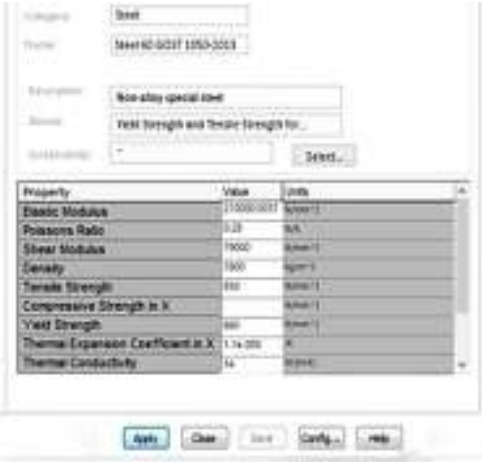

(imi $-\infty$

Fig. 5 Mechanical properties of the materials inSolidWorks Library.

By using Solid works simulation software, we analyzed stresses, displacements, deformations and safety factor for each material for the part "Flange half of differential case". Fig. 6 (a-i), demonstrates the results of modelling for steel Mst.6.
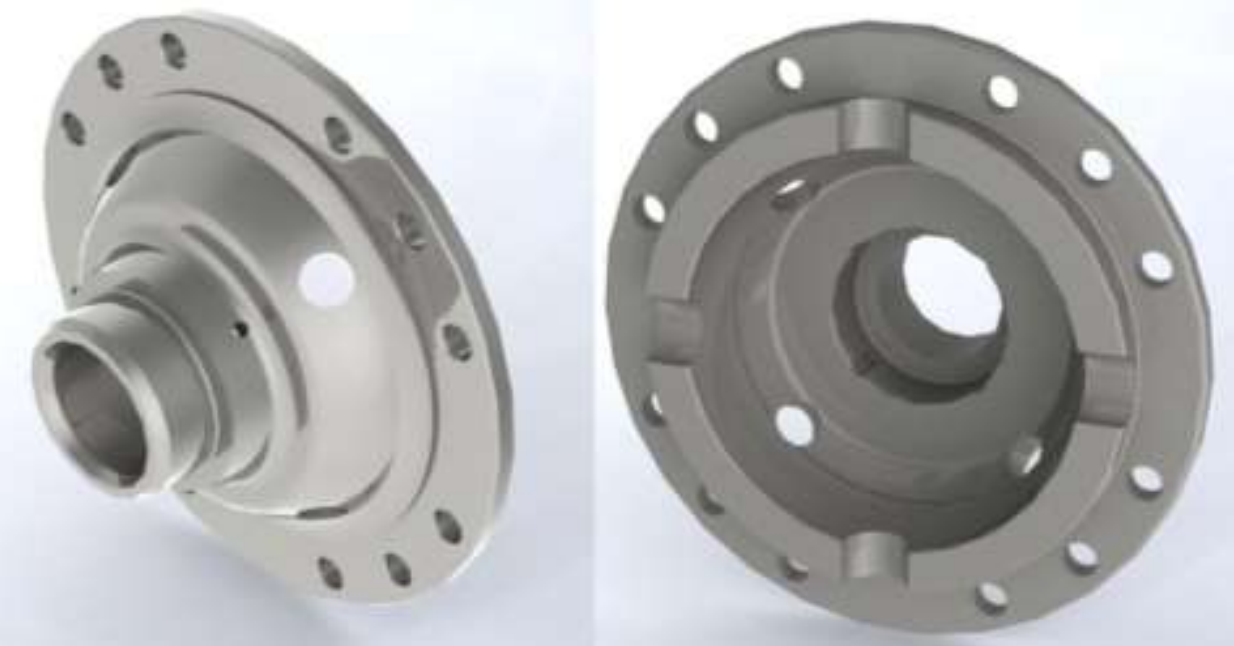

Fig. 6a The results of modelling of part "Flange half of differential case", made of steel MSt.6: general view of the model

As for results for other materials, they are given in Table 1. 


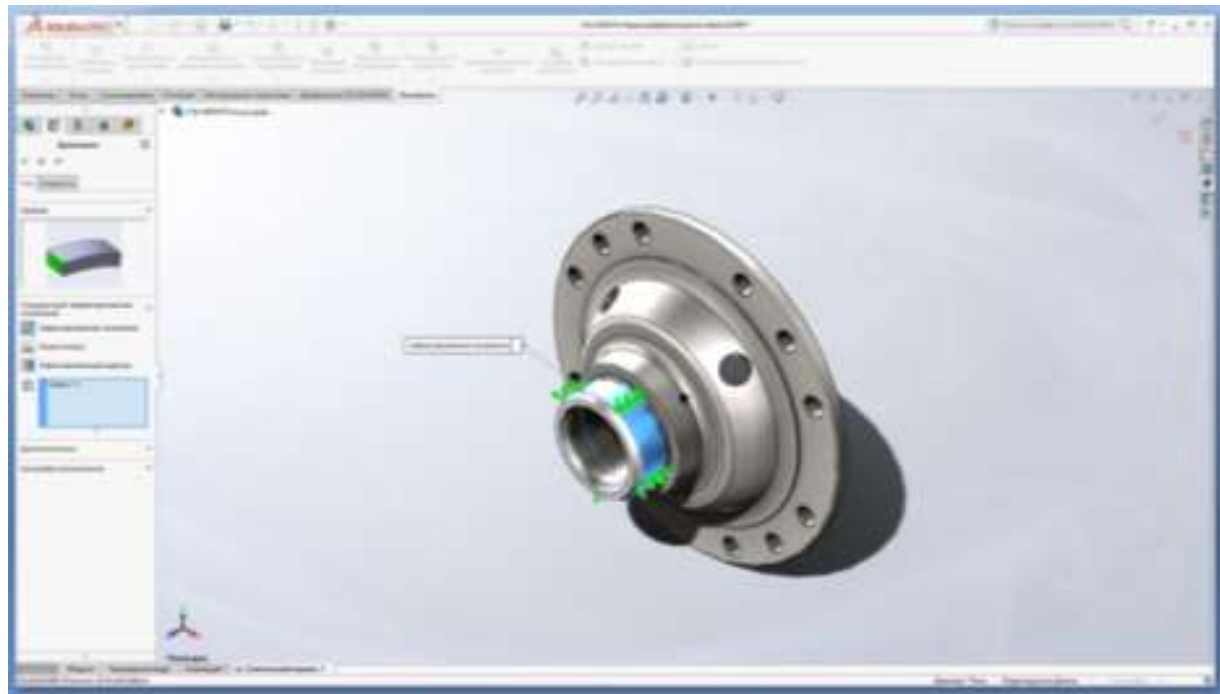

Fig. 6b The results of modelling of part "Flange half of differential case", made of steel MSt.6: general view of the model, start of modelling

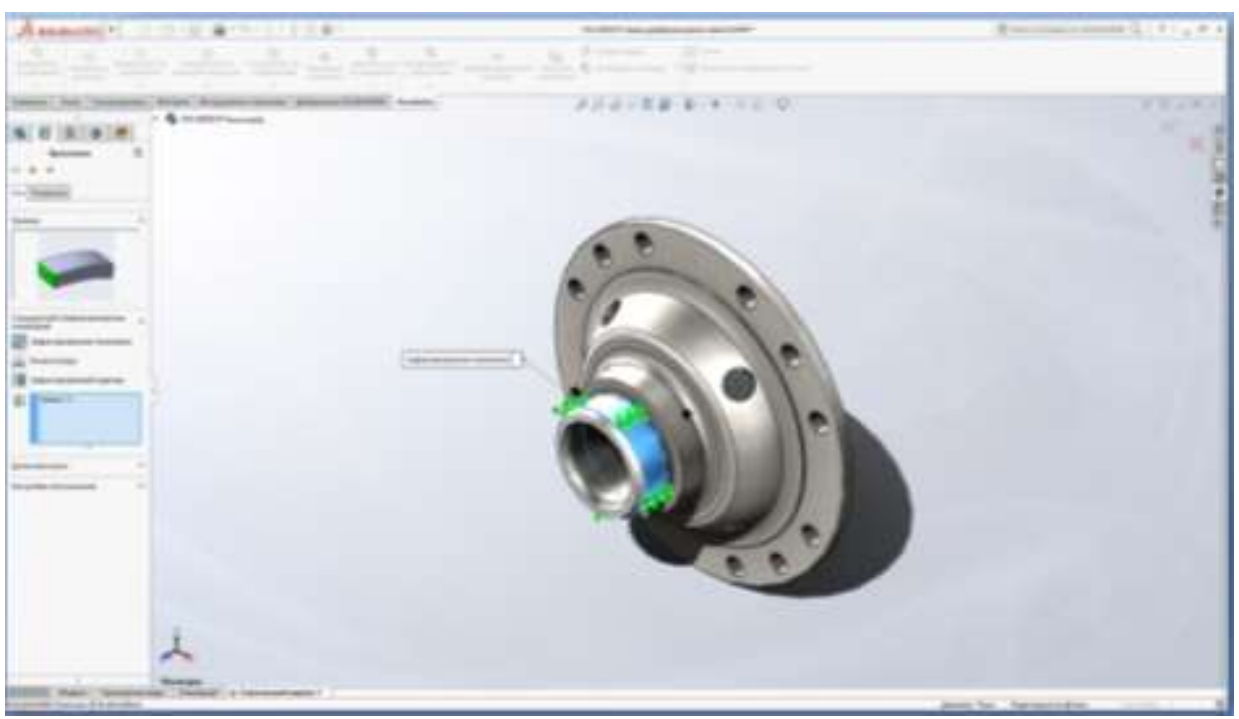

Fig. $6 c$ The results of modelling of part "Flange half of differential case", made of steel MSt.6: grid on the part

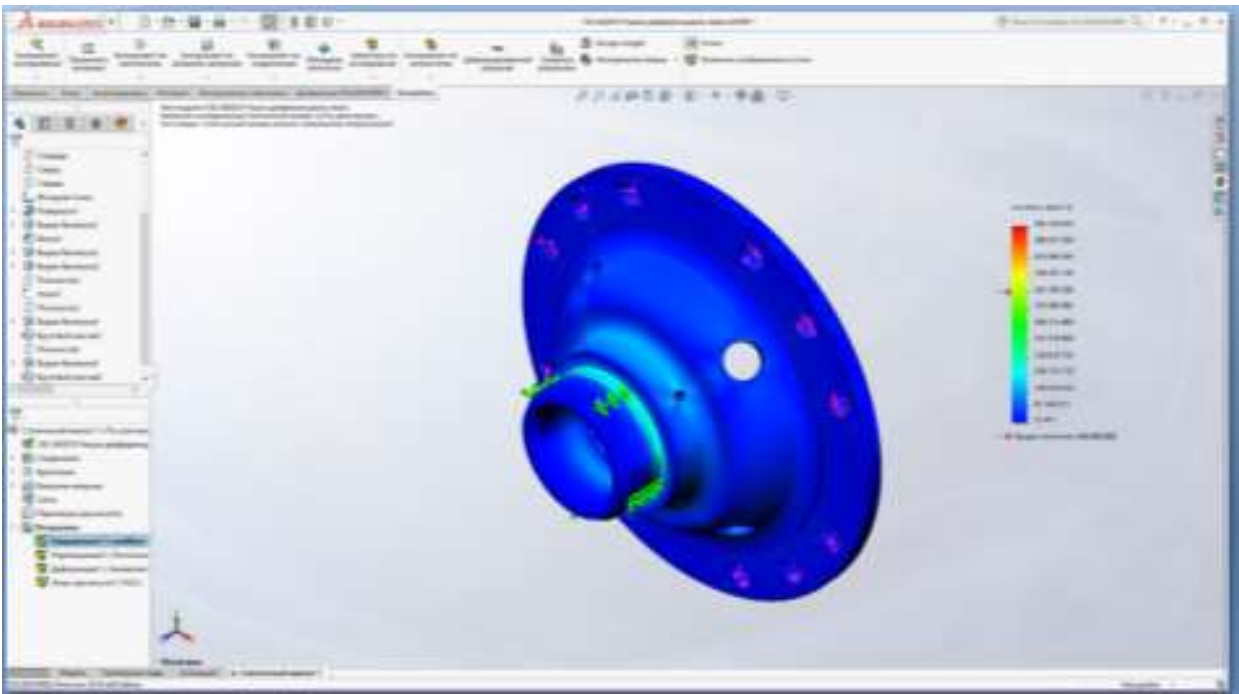

Fig. $6 \mathrm{~d}$ The results of modelling of part "Flange half of differential case", made of steel MSt.6: stresses 


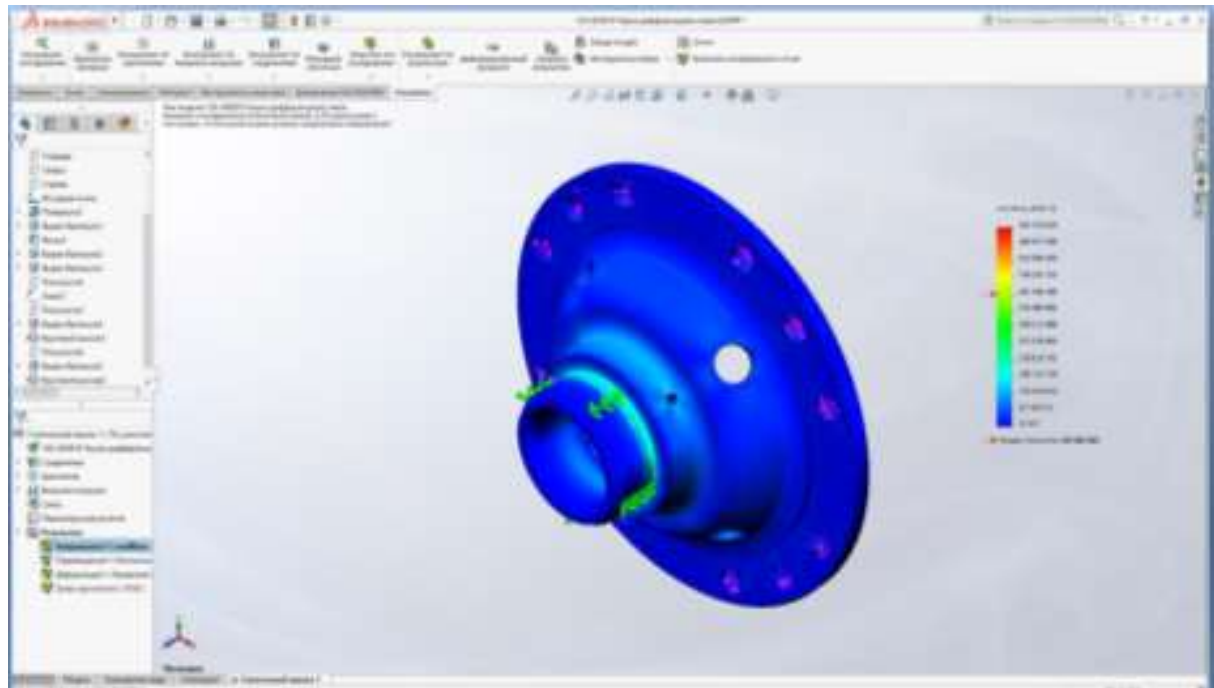

Fig. $6 f$ The results of modelling of part "Flange half of differential case", made of steel MSt.6: displacements in units of the part

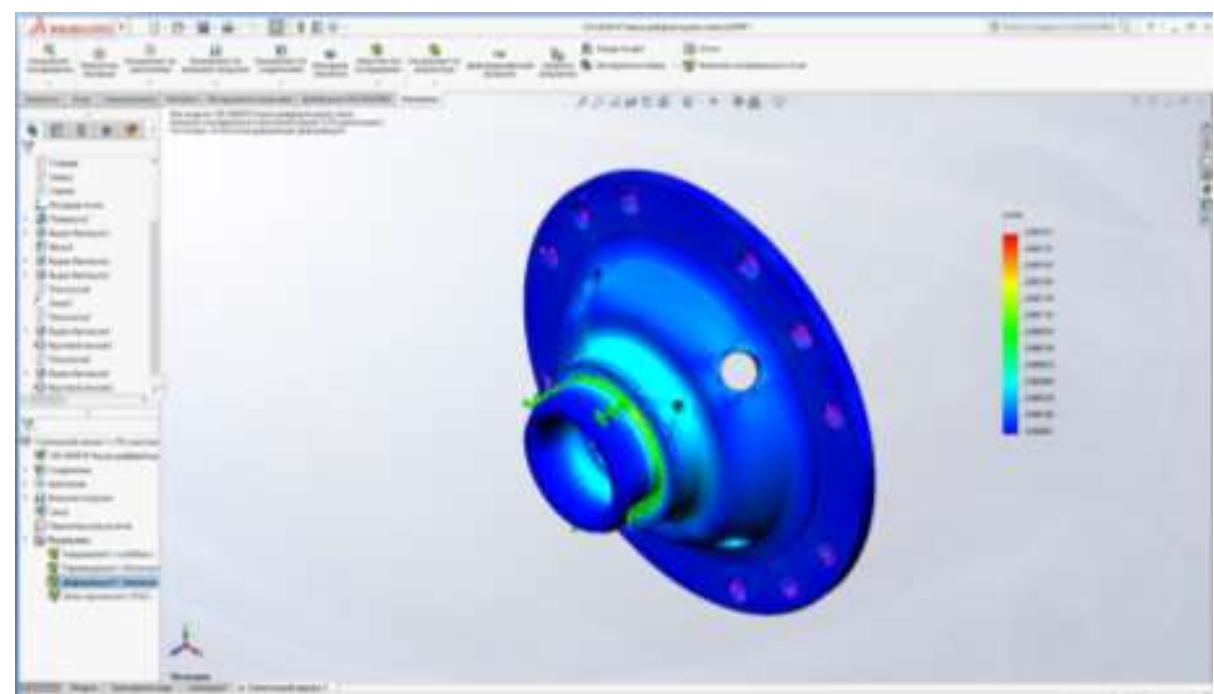

Fig. $6 \mathrm{~g}$ The results of modelling of part "Flange half of differential case", made of steel MSt.6:, deformations

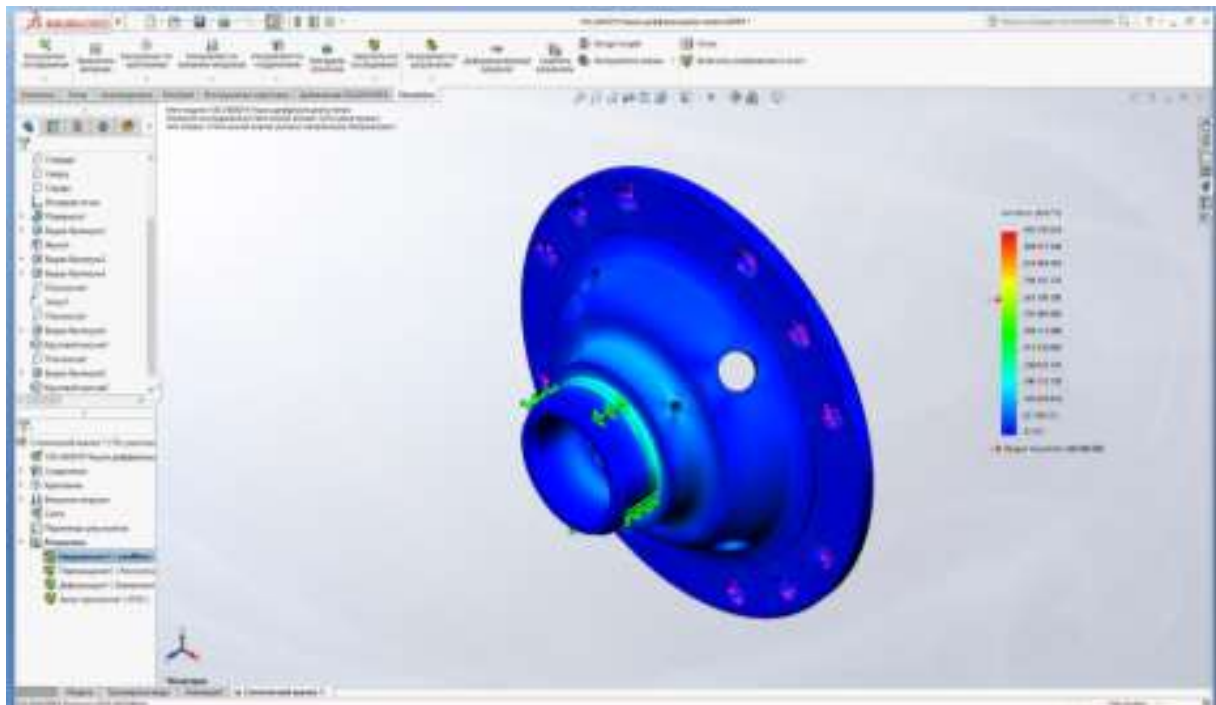

Fig. $6 \mathrm{~h}$ The results of modelling of part "Flange half of differential case", made of steel MSt.6: safety factor 


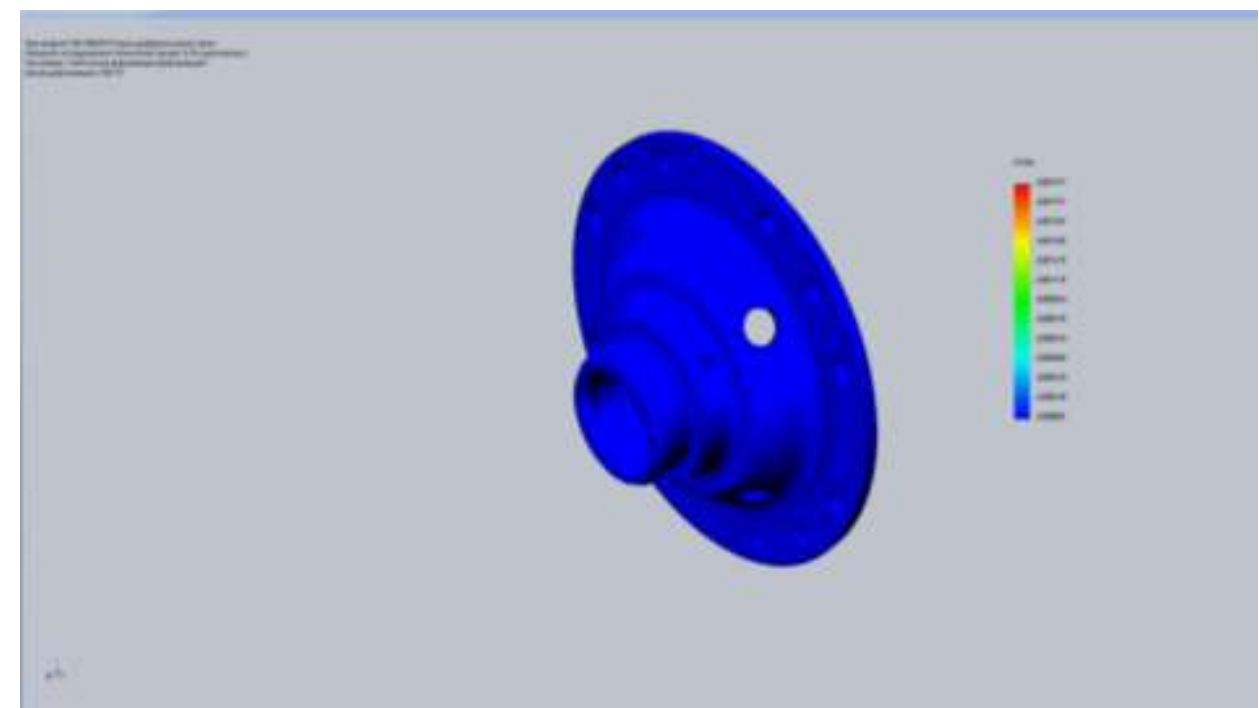

Fig. $6 i$ The results of modelling of part "Flange half of differential case", made of steel MSt.6: total deformation with scales

Table 1 Data from the analysis of modelling of the part

"Flange half of differential case"

\begin{tabular}{|l|c|c|c|c|}
\hline Material & $\begin{array}{c}\text { Maximum } \\
\text { stress, } \\
{[\mathrm{MPa}]}\end{array}$ & $\begin{array}{c}\text { Maximum } \\
\text { displacement, } \\
{[\boldsymbol{\mu \mathrm { m } ]}}\end{array}$ & $\begin{array}{c}\text { Maximum } \\
\text { deformation, } \\
{[\boldsymbol{\mu \mathrm { m } ]}]}\end{array}$ & $\begin{array}{c}\text { Minimum } \\
\text { safety factor } \\
{[-]}\end{array}$ \\
\hline Steel 45 & 580 & 96 & 11 & 1.416 \\
\hline Steel 60 & 660 & 96 & 11 & 1.611 \\
\hline SCH15 & 101 & 247 & 3 & 0.246 \\
\hline SCH30 & 226 & 165 & 2 & 0.522 \\
\hline L60 & 200 & 210 & 2 & 0.485 \\
\hline ABS 2020-31 & 38,2 & 10817 & 131 & - \\
\hline
\end{tabular}

Source: (Competence Center "Technological Modeling", 2019)

\section{DISCUSSION}

To choose the optimum method for manufacturing of the workpiece, it is necessary to analyze the influence of several factors on the part. They include material (Shmakov et al., 2019), shape, overall dimensions (Kolmogortsevl et al., 2016), weight, technical requirements, volume and serial production (Cheslavskaya et al., 2015), material utilization ratio (Competence Center "Technological Modeling", 2019).

Eventually, we should choose the method providing the maximum manufacturability, minimum labor input and lowest cost price.

The material is the one of key aspects governing the manufacturing method for the workpiece. In accordance with structure and operational characteristics of the part the optimum variant is steel 45GOST1050-2013 (international analogues include 1044, 1045 (USA), 1.1191, 2C45 (European Union), 45 (Poland), 12050, 12056 (Czech Republic)), which belongs to the class of quality structural carbon steels (Table 1). This steel can't be used for casting as its chemical composition and mechanical properties do not meet the requirements. The closest analogue steel, from which the part can be made, is steel $45 \mathrm{~L}$ (сталь 45Л) that meets the requirements of GOST 977-88 (ГOCT 977-88). However, 
this analogue has higher plasticity and lower tensile strength, which can reduce the operational life of the part.

Theoretical research on selection of the material for part "Flange half of differential case" showed that it is reasonable to use forgings and round bars as workpieces.

The part has complex cylindrical design shape with curved surfaces and central through-hole. Taking into account the features of the construction, punching and casting methods are most likely for workpiece manufacturing. Manufacturing from round bars is the least cost-efficient method and requires considerable labor input.

Two types of workpieces meet the technical requirements for the part, they include forging and casting.

By analyzing the type of production and the weight of the part, all methods for producing workpieces can be selected, but with limitations. The use of round bars is impossible because of the extremely low rates of material consumption. The creation of forgings by open die forging is also not reasonable with respect to the high labor input and low accuracy of the workpieces obtained, the use of castings in this case requires a partial change in design or a decrease in the operational characteristics of the final product.

The final factor in choosing the method of workpiece manufacturing is to determine the material utilization ratio (Groover, 2010).

Types of workpieces considered include castings, forgings, formed during hot die forging, round bars from rolled metal (Fig. 7-9). We have not considered such methods of workpieces production as cold forging and powder compression, because it is impossible to create required design of the part from the workpieces obtained by these methods.

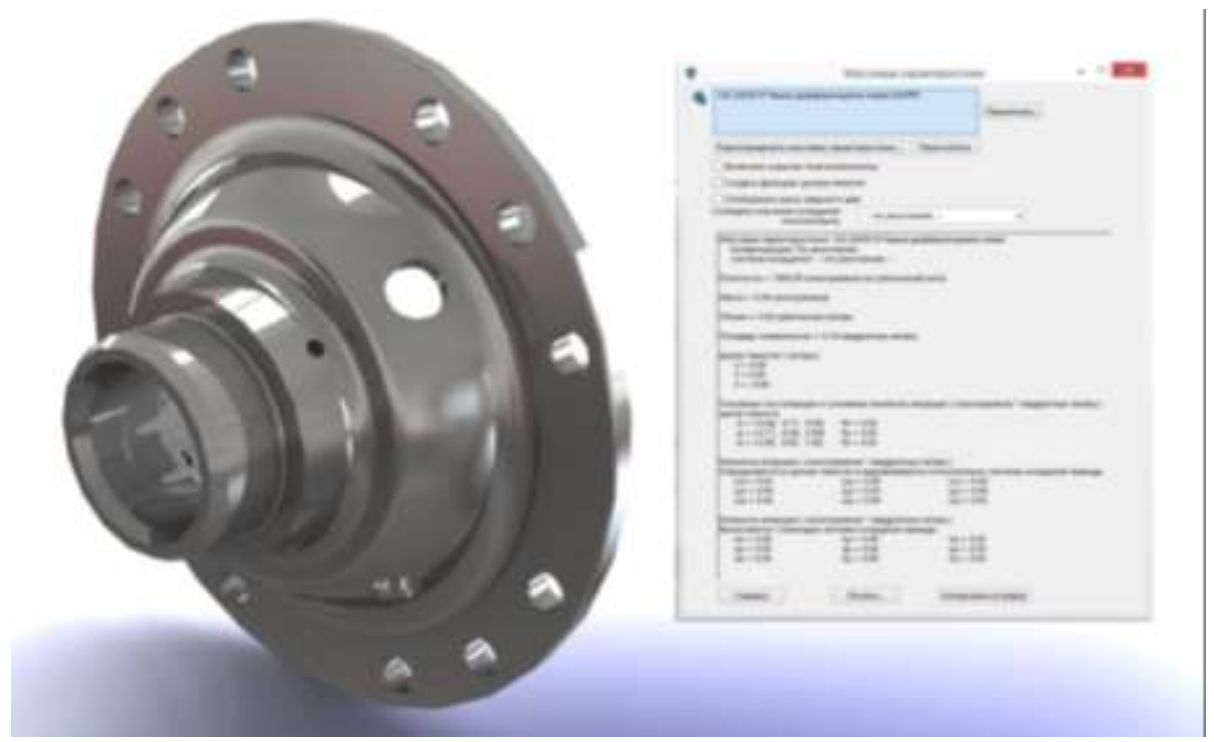

Fig. 7 Mass properties of produced part 


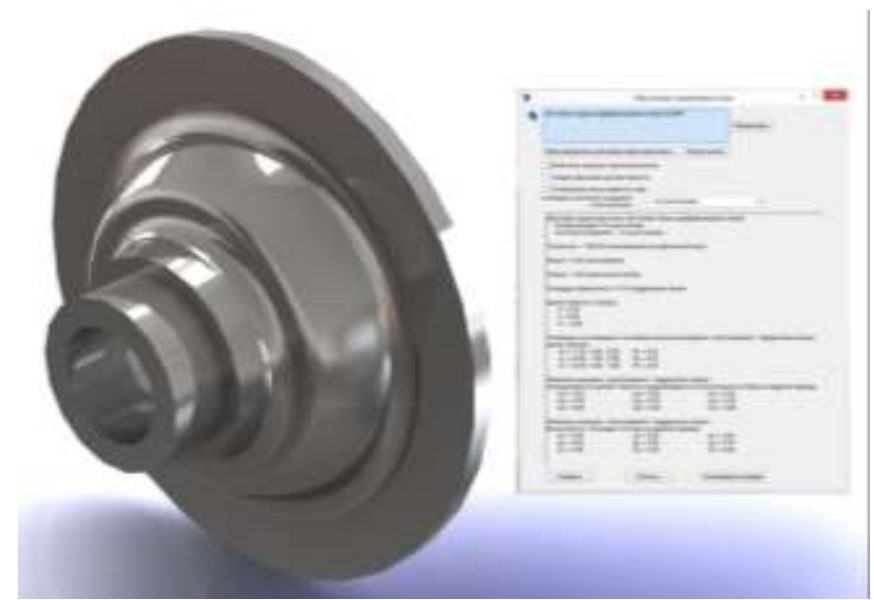

Fig. 8 Mass properties of forging

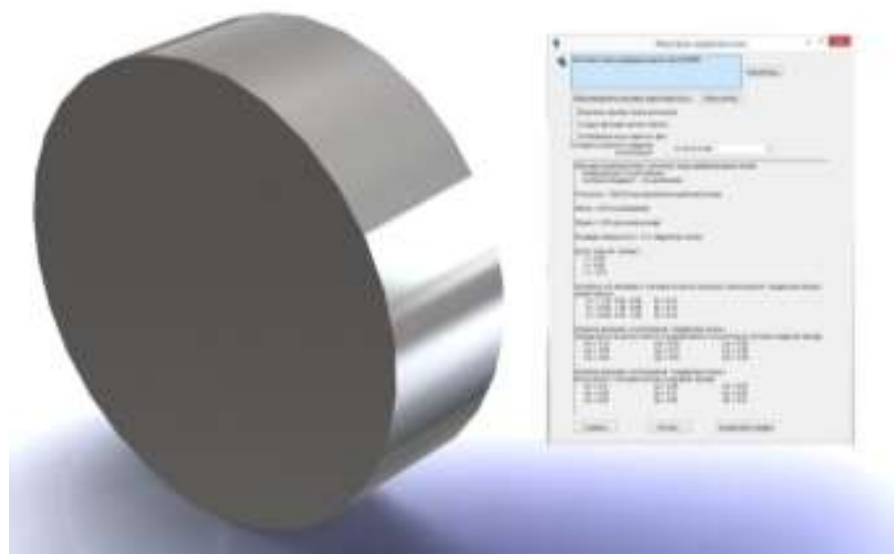

Fig. 9 Mass properties of round bar

The calculation of material utilization coefficient the utilization of the material $K_{\text {u.m. }}$ For round bar:

$$
\mathrm{K}_{u . \mathrm{M.}}=\frac{m_{\text {part }}}{m_{\text {workpiece }}}=\frac{6.58}{32.5}=0.20 \prec \mathrm{K}_{\text {и.M. }}^{\text {normative }}=0.75
$$

where:

$m_{\text {part, }} m_{\text {workpiece }}$ stand for mass of the part and mass of the workpiece, respectively.

As $0.20<0.75$, the part is not fabricable for this indicator. For forging:

$$
\mathrm{K}_{u . \mathrm{M.}}=\frac{m_{\text {part }}}{m_{\text {workpiece }}}=\frac{6.58}{8.36}=0.79>\mathrm{K}_{\text {и.M. }}^{\text {normative }}=0.75
$$

As $0.79>0.75$, the part is fabricable for this indicator.

According to the analyzed factors, the most reasonable workpiece is a forging, made by hot die forging method with the use of horizontal forging machine. Forging design consists of assigning tolerances and allowances for machining in accordance with GOST 7505-89 (ГОСТ 7505-89). During fabricability test we identified the surfaces, which will be absent on the workpiece. Their absence is connected with impossibility to create these surfaces in the workpiece because of complex geometry or small size. Another reason is structural and technological simplification of the workpiece aimed at a decrease in defects (Fig. 10). 

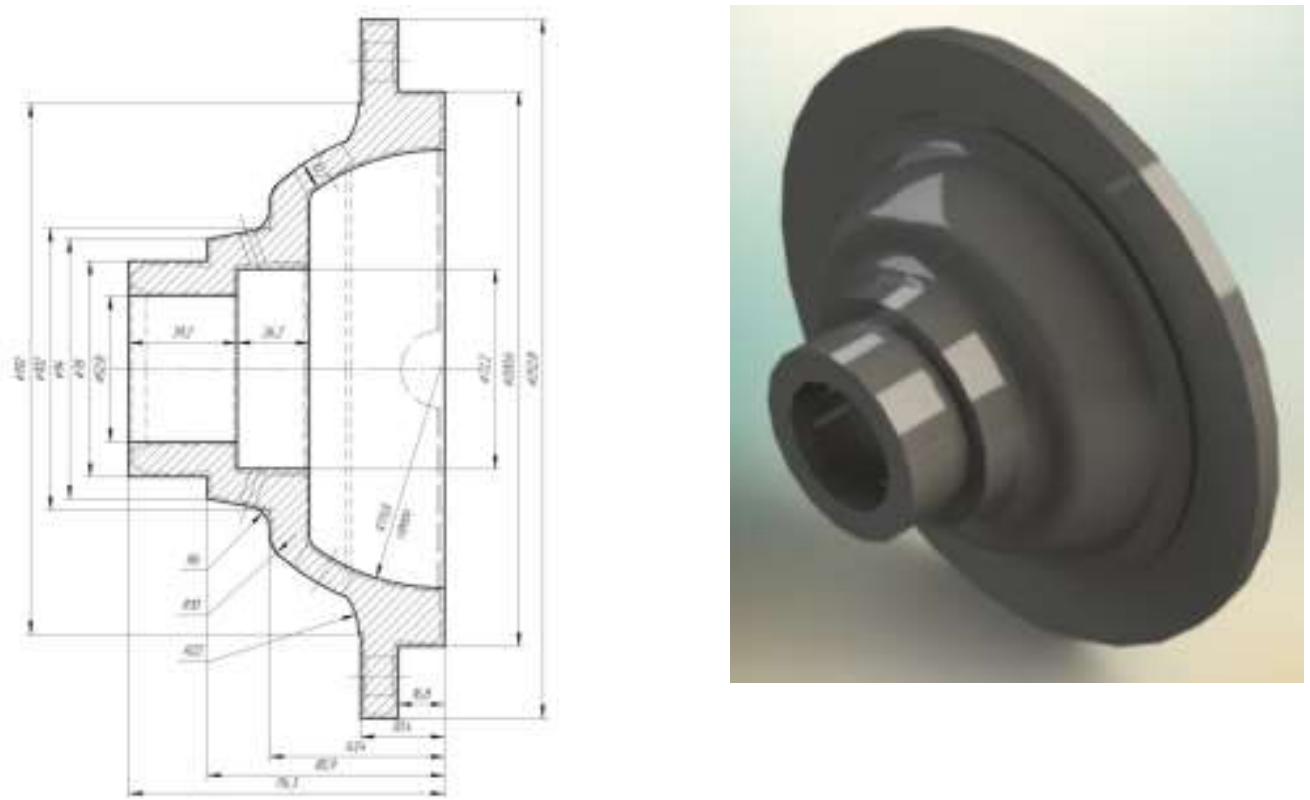

Fig. 10 Sketch of the workpiece with the assigned dimensions and a 3D-model of the workpiece

To substantiate the selection of the up-to-date analogue material, the research has been fulfilled, which takes into account technical requirements for the part, design manufacturability, feasibility of geometric and accuracy parameters, machinability by cutting, feasibility of other requirements according to OST 95227-92 (OCT 95227-92).

For modelling we have chosen the following materials for production of "Flange half of differential case": Mst.6 GOST 380-50 (МСт.6 ГОСT 380-50), steel 45 GOST 1050-2013 (сталь 45 ГOCT 1050-2013), steel 60 GOST 1050-2013 (сталь 60 ГОСТ 1050-2013), grey cast iron SCH15 GOST 1412-85 (C415 ГOCT 1412-85), grey cast iron SCH30 GOST 1412-85 (C430 ГOCT 1412-85), aluminum AK7 GOST 1583-93 (AK7 ГOCT 1583-93), latten L60 GOST 155272004 (Л60 ГОСТ 15527-2004), plastic ABS 2020-31 TS2214-019-00203521-96 (AБC 2020-31 TУ 2214-019-00203521-96), which are shown on Fig. 11. The characteristics of the materials are demonstrated in Tables 2, 3.

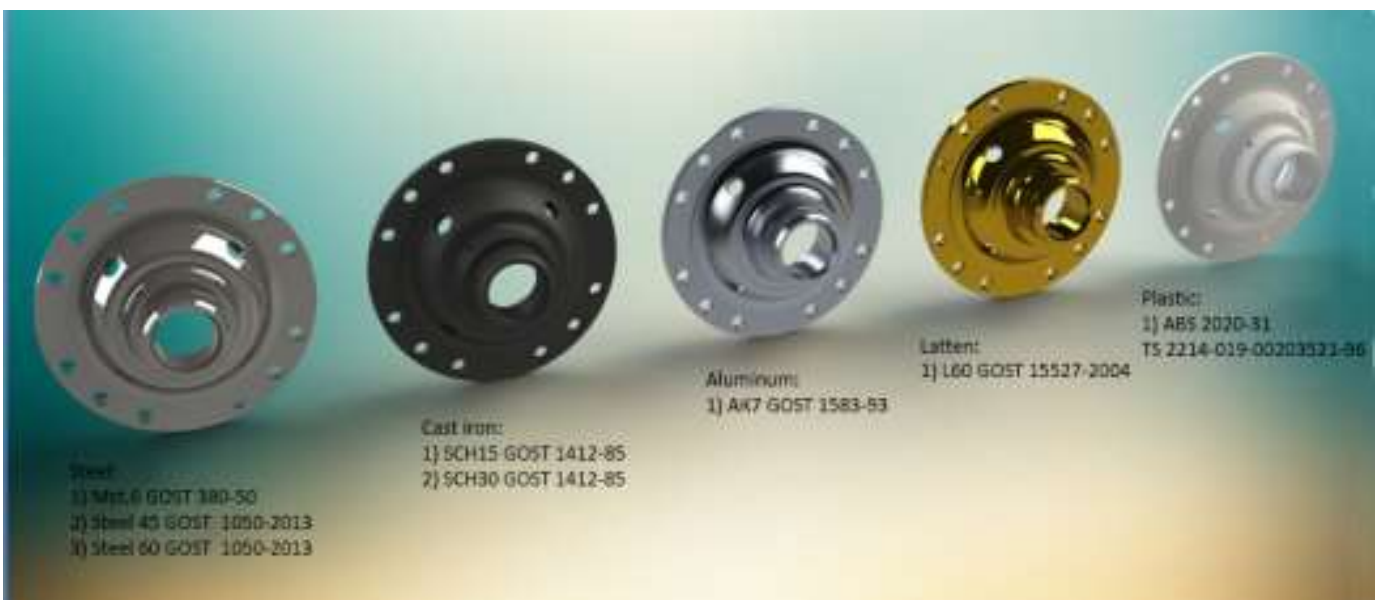

Fig. 11 3D-modelsof "Flange half of differential case" 
Table 2 Chemical composition of the materials, $\%$

\begin{tabular}{|c|c|c|c|c|c|c|c|c|c|c|}
\hline Material & C & $\mathrm{Si}$ & Mn & $\mathbf{N i}$ & $\mathrm{S}$ & $\mathbf{P}$ & $\mathrm{Cr}$ & $\mathrm{Cu}$ & As & $\mathrm{Fe}$ \\
\hline $\begin{array}{l}\text { Steel } \\
\text { MSt.66 }\end{array}$ & $\begin{array}{l}0.38- \\
0.50\end{array}$ & $\begin{array}{l}0.17- \\
0.35\end{array}$ & $\begin{array}{l}0.50- \\
0.80\end{array}$ & $\begin{array}{l}\text { Upto } \\
0.25\end{array}$ & 0.055 & 0.050 & $\begin{array}{l}\text { upto } \\
0.25\end{array}$ & $\begin{array}{l}\text { upto } \\
0.25\end{array}$ & $\begin{array}{l}\text { upto } \\
0.08\end{array}$ & $\sim 97$ \\
\hline Steel 45 & $\begin{array}{l}0.42- \\
0.50\end{array}$ & $\begin{array}{l}0.17- \\
0.37 \\
\end{array}$ & $\begin{array}{l}0.50- \\
0.80 \\
\end{array}$ & $\begin{array}{l}\text { upto } \\
0.30 \\
\end{array}$ & $\begin{array}{l}\text { upto } \\
0.035 \\
\end{array}$ & $\begin{array}{l}\text { Upto } \\
0.030\end{array}$ & $\begin{array}{l}\text { upto } \\
0.25 \\
\end{array}$ & $\begin{array}{l}\text { upto } \\
0.30 \\
\end{array}$ & $\begin{array}{l}\text { upto } \\
0.08 \\
\end{array}$ & $\sim 97$ \\
\hline Steel 60 & $\begin{array}{l}0.57- \\
0.65 \\
\end{array}$ & $\begin{array}{l}0.17- \\
0.37 \\
\end{array}$ & $\begin{array}{l}0.50- \\
0.80 \\
\end{array}$ & $\begin{array}{l}\text { upto } \\
0.25 \\
\end{array}$ & $\begin{array}{l}\text { upto } \\
0.040 \\
\end{array}$ & $\begin{array}{l}\text { Upto } \\
0.35 \\
\end{array}$ & $\begin{array}{l}\text { upto } \\
0.25 \\
\end{array}$ & $\begin{array}{l}\text { upto } \\
0.25 \\
\end{array}$ & $\begin{array}{l}\text { upto } \\
0.08 \\
\end{array}$ & $\sim 97$ \\
\hline $\begin{array}{l}\text { Cast iron } \\
\text { SCH15 }\end{array}$ & $\begin{array}{l}3.50- \\
3.70 \\
\end{array}$ & $2-2.4$ & $\begin{array}{l}0.50- \\
0.80\end{array}$ & & $\begin{array}{l}\text { upto } \\
0.150\end{array}$ & $\begin{array}{l}\text { Upto } \\
0.2 \\
\end{array}$ & & & & $\sim 93$ \\
\hline $\begin{array}{l}\text { Cast iron } \\
\mathrm{SCH} 30\end{array}$ & $\begin{array}{l}3.00- \\
3.20 \\
\end{array}$ & $\begin{array}{l}1.3- \\
1.9 \\
\end{array}$ & $\begin{array}{l}0.70- \\
1.00 \\
\end{array}$ & & $\begin{array}{l}\text { Upto } \\
0.120 \\
\end{array}$ & $\begin{array}{l}\text { Upto } \\
0.2 \\
\end{array}$ & & & & $\sim 93$ \\
\hline $\begin{array}{l}\text { Aluminum } \\
\text { AK7 }\end{array}$ & $\begin{array}{l}\mathrm{Mg} \\
0.20- \\
0.50 \\
\end{array}$ & $6-8$ & $\begin{array}{l}0.20- \\
0.60\end{array}$ & $\begin{array}{l}\text { Upto } \\
0.30\end{array}$ & $\begin{array}{l}\mathrm{Zn} \\
\text { upto } \\
0.500 \\
\end{array}$ & & & $\begin{array}{l}\text { upto } \\
1.50\end{array}$ & $\begin{array}{l}\mathrm{AL} \\
85.1- \\
91.6 \\
\end{array}$ & $\begin{array}{l}\text { upto } \\
1.3\end{array}$ \\
\hline $\begin{array}{l}\text { Latten } \\
\text { L60 }\end{array}$ & & & & $\begin{array}{l}\mathrm{Pb} \\
0.30 \\
\end{array}$ & $\begin{array}{l}\mathrm{Sb} \\
0.010 \\
\end{array}$ & 0.01 & & $\begin{array}{l}0.59- \\
0.62 \\
\end{array}$ & & 0.2 \\
\hline
\end{tabular}

Source: (Competence Center "Technological Modeling”, 2019).

Table 3 Mechanical properties of the materials

\begin{tabular}{|c|c|c|c|c|c|c|}
\hline \multirow[b]{2}{*}{ Material } & \multicolumn{6}{|c|}{ Mechanical properties, no less than } \\
\hline & $\begin{array}{c}\text { Yield } \\
\text { strength } \\
\sigma_{\mathrm{T}} \\
{\left[\mathrm{N} / \mathrm{mm}^{2}\right]}\end{array}$ & $\begin{array}{c}\text { Ultimate } \\
\text { tensile } \\
\text { strength } \\
\sigma_{\mathrm{B}}, \\
{\left[\mathrm{N} / \mathrm{mm}^{2}\right]}\end{array}$ & $\begin{array}{c}\text { Relative } \\
\text { elongation } \\
\text { of area } \\
\delta,[\%]\end{array}$ & $\begin{array}{c}\text { Relative } \\
\text { reduction } \\
\text { of area } \\
\Psi,[\%]\end{array}$ & $\begin{array}{c}\text { Elastic } \\
\text { modulus } \\
\text { E10-2, } \\
{\left[\mathrm{N} / \mathrm{mm}^{2}\right]}\end{array}$ & $\begin{array}{c}\text { Hardness } \\
\text { HB }\end{array}$ \\
\hline MSt.66 & 510 & 730 & 19 & - & 2 & \\
\hline steel 45 & 580 & 750 & 19 & 42 & 2 & 170 \\
\hline steel 60 & 660 & 850 & 20 & 58 & $1.74-2.04$ & $370-450$ \\
\hline SCH15 & & 150 & & & $700-1100$ & $163-229$ \\
\hline SCH30 & & 300 & & & $1200-1450$ & $187-255$ \\
\hline AK7 & & 167 & 1 & & & 50 \\
\hline L60 & & 650 & $2-4$ & & & 165 \\
\hline $\begin{array}{c}\text { ABS } \\
2020-31\end{array}$ & 382 & & 22 & & 2 & \\
\hline
\end{tabular}

Source: (Competence Center "Technological Modeling", 2019)

\section{CONCLUSIONS}

As a result of the study, it was found out that the manufacture of this part is permissible only from steel. Comparison of the results of steels satisfying the technical requirements for the part "Flange half of differential case" is shown in Fig. 12.

As a result of evaluation of other parameters the cheapest material has been chosen. It is the steel 45 GOST1050-2013, which demonstrates the closest properties, to initial material MSt.6 GOST 380-50.

The results of modelling of "Flange half of differential case" allowed us to make recommendations for production conditions. These recommendations include the use of steel 45 GOST 1050-2013 as the analogue material, hot forging of a workpiece on a horizontal forging machine, creating of design and technological documentation for the manufacture of the part. 

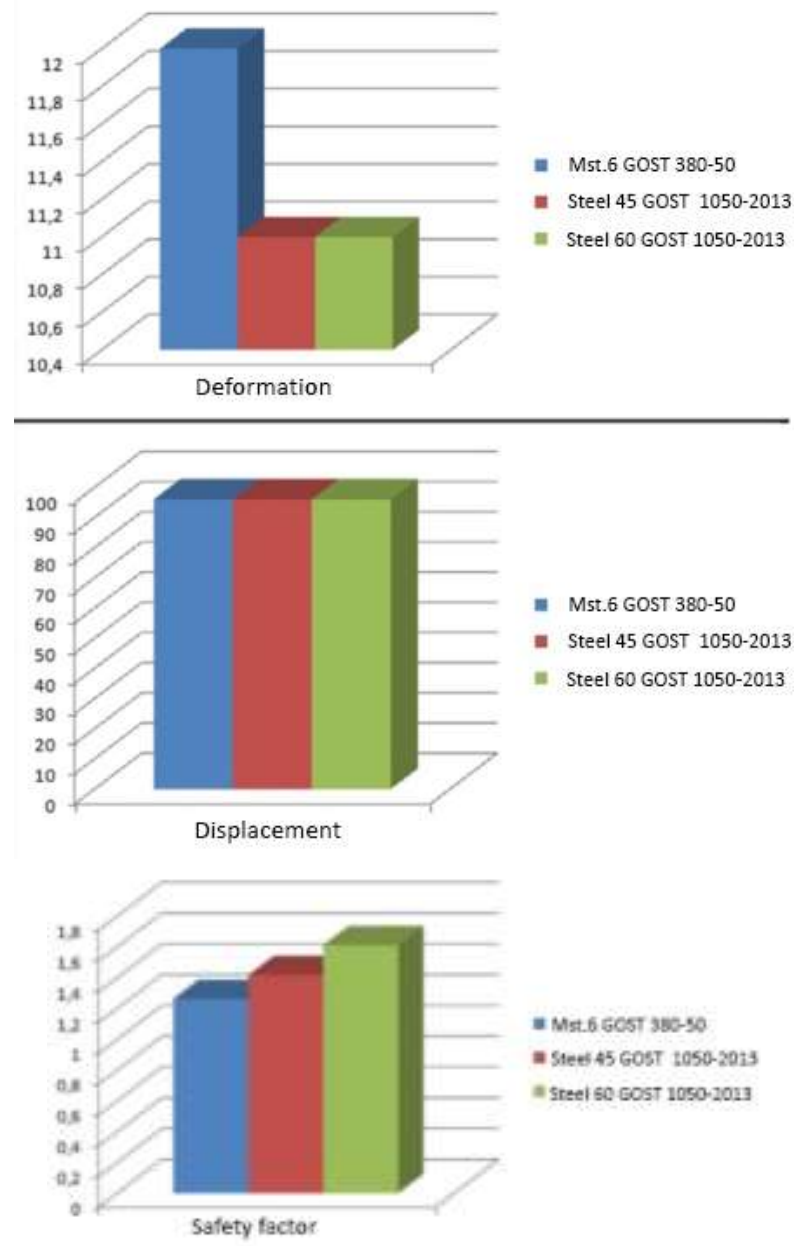

Fig. 12 Comparison of results of modeling from steels

\section{ACKNOWLEDGEMENTS}

The work was financially supported by the Russian Foundation for Basic Research (RFBR), grant No. 18-48-80006 p_a, and research project VEGA 1/0019/20.

\section{REFERENCES}

Ajaja, J., Jomaa, W., Bocher, P., Chromik, R.R. and Brochu, M. (2020). High cycle fatigue behavior of hard turned $300 \mathrm{M}$ ultra-high strength steel. Int. J. Fatigue. 131, 105380.

Beno, M., Zvoncan, M. and Kovac, M. (2013). Circular interpolation and positioning accuracy deviation measurement on five axis machine tools with different structures. Tehnicki Vjesnik-Technical Gaz., 20, pp. 479-484.

Božek, P. (2013). Robot path optimization for spot welding applications in automotive industry. In Tehnički Vjesnik - Technical Gazette. 20, 5, pp. 913-917. ISSN 13303651

Božek, P. and Pivarčiová, E. (2012). Registration of Holographic Images Based on Integral Transformation. In Computing and Informatics. 31, 6, pp. 1369-1383.

Božek, P. (2014). Automated Detection Type Body and Shape Deformation for Robotic Welding Line. In: Advances in Intelligent Systems and Computing: Proceedings of the International Conference on Systems Science 2013, ICSS 2013; Wroclaw; Poland; 10 September 2013 through 12 September 2013. pp. 229-240. ISSN 2194-5357. 
Competence Center "Technological Modeling". (2019). Retrieved from: http://www.technology.ru.com/, free.

Gładysiewicz, L. Król, R. Kisielewski, W. Kaszuba, D. (2017). Experimental determination of belt conveyors artificial friction coefficient, Acta Montanistica Slovaca Volume 22 (2017), number 2, pp. 206-214

Groover, Mikell P. (2010). Fundamentals of modern manufacturing: materials, processes and systes, 4th ed., John Wiley \& Sons, Inc, $1013 \mathrm{p}$.

Cheslavskaya, A.A, Mironenko, V.V. and Kolesnikov, A.V. (2015). Choosing an efficient method for forming parts by means of an engineering analysis performed with the use of a cae system. Metallurgist. Vol 58 Nos. 11-12 March.

Jurko, J.; Džupon, M.; Panda, A.; Gajdoš, M.; Pandova, I. (2011). Deformation of Material Under the Machined Surface in the Manufacture of Drilling Holes in Austenitic Stainless Steel, in: Chemicke listy, pp. 600-602.

Klaic, M., Staroveski, T. and Udiljak, T. (2014). Tool Wear Classification using Decision Treesin Stone Drilling Applications: A Preliminary Study. Procedia Eng., 69, pp. 1326-1335.

Kolmogortsevl, V., Ledovskikh, E.V, Osipov, S.A. and Shmakov, A.K. (2016). Analysis of the thermal state of a semifinished product during hot die forging. Metallurgist, Vol 59 Nos. 11-12 March.

Leonid, B., Aksenov, Sergey N. Kunkin. (2016). Metal flow ontrol at processes of cold axial rotary forging. In: Advances in Mechanical Engineering, Lecture Notes in Mechanical Engineering, Springer International Publishing, Switzerland.

Luschtinetz, T. et al., (2019). The selected results of the experimental research of solid fuel pneumatic transportation to ship's boiler, Management Systems in Production Engineering 2019, Volume 27, Issue 3, pp. 144-148, DOI 10.1515/mspe-2019-0023

Peterka. J. (2004). A new approach to calculating the arithmetical mean deviation of a profile during copy milling. Strojniški Vestnik J. Mech. Eng., 50, pp. 594-597.

Pokorný, P., Peterka, J. and Vaclav, S. (2012). The task of 5-axis milling. Tehnicki Vjesnik-Technical Gaz. 19, pp. 147-150.

Sentyakov, K., Peterka, J., Smirnov, V., Bozek, P. and Sviatskii, V. (2020). Modeling of Boring Mandrel Working Process with Vibration Damper. Materials, 13(8), 1931; https://doi.org/10.3390/ma13081931.

Shmakov, A., Osipov, S. and Kudryavtsev, A. (2019). Experience in applying digital modeling to improve component manufacturing. In: IOP Conf. Series: Materials Science and Engineering. 632, 012097.

Skoric, S., Udiljak, T., and Ciglar, D. (2008). Study of the suitability of the machining of rotating surfaces. J. Trans. Famena. 32, pp. 69-83.

Thipprakmas, Sutasn and Phanitwong, Wiriyakorn. (2011). Finite element analysis of flange-forming direction in the hole flanging process. The International Journal of Advanced Manufacturing Technology. 61. 10.1007/s00170-011-3721-8.

Technology Evaluation Centers: Top Computer-Aided Engineering (CAE) Software. (2020). Available on the Internet: https://www.secotools.com/article/662). [cit. 2020-06-17].

Vopat, T., Peterka, J., Kovac, M. and Buranský, I. (2013). The wear measurement process of ball nose end mill in the copy milling operations. In Proceedings of the 24th DAAAM International Symposium on Intelligent Manufacturing and Automation, Zadar, Croatia, 23-26 October 2013.

Vopat, T., Peterka, J. and Šimna, V. (2015). The influence of different types of copy milling on the surface roughness and tool life of end mills. Procedia Eng., 100, pp. 868-876.

Zhou, H. (2010). Design of Tread Flange Injection Mold Based on Pro/E. 555-562. 10.1007/978-3-642-18369-0_66. 
Zou, F., Dang, J., Cai, X., An, Q., Ming, W. and Chen, M. (2020). Hole quality and tool wear when dry drilling of a new developed metal/composite co-cured material. Proc. Inst. Mech. Eng. Part B J. Eng. Manuf., 234, pp. 980-992.

Xun, X. (2009). Integrating Advanced Computer-Aided Design, Manufacturing, and Numerical Control: Principles and Implementations, IGI Global, Hershey, ISBN 978-1-59904-714-0.

\begin{abstract}
The object of the research is a part "Flange half of differential case", which has complex shape of a housing. The subjects of the research are the processes of selection of analogue material, workpiece production method, and justification of the structural and technological parameters of a part, taking into account 3D-modeling of the structure, deformations, displacements, stresses, and safety factor. The selection of analogue material is connected with suspension of production of open-hearth steel grade Mst.6 GOST 380-50. The objectives of the work include juxtaposition of computer models of deformations, displacements, stresses, safety factors of the part made of different analogue materials; comparison of models according workpiece production methods with consideration of material utilization ratio, structural and technological features of resulting workpieces. For modelling we have chosen the several types of materials. Research on modelling processes was fulfilled by means of software of Kompasv17, Solid Works, Solid works simulation. Volumetric models of parts and workpieces for all studied materials have been created taking into account the deformations, displacements, stresses, and safety factor. There results of modelling of "Flange half of differential case" allowed us to make recommendations for production conditions. These recommendations include the use of steel 45 GOST 1050-2013 as analogue material, hot forging of a workpiece on a horizontal forging machine, creating of design and technological documentation for the manufacture of the part.
\end{abstract}

Keywords: modelling, production technology, CAD/CAM, machining 